\title{
PERBEDAAN PENGETAHUAN IBU SEBELUM DIBERI PENYULUHAN DAN SETELAH DIBERI PENYULUHAN TENTANG STIMULASI PERKEMBANGAN ANAK USIA 0-3 TAHUN (Di Posyandu 5 Kelurahan Srengat Kecamatan Srengat Kabupaten Blitar)
}

Rofik Darmayanti ${ }^{1}$, Fitria Pangestuti ${ }^{2}$

Akademi Kebidanan Dhara Husada Kediri

\begin{abstract}
ABSTRAK
Stimulasi perkembangan yang dilakukan oleh ibu maupun keluarga sangat berpengaruh besar terhadap perkembangan seorang anak. Kurangnya pemberian stimulasi dapat menyebabkan penyimpangan tumbuh kembang bahkan gangguan yang menetap. Penelitian ini bertujuan untuk menganalisa perbedaan pengetahuan ibu sebelum diberi penyuluhan dan setelah diberi penyuluhan tentang stimulasi perkembangan anak usia 0-3 tahun.

Desain penelitian yang digunakan adalah pre-experimental design dengan menggunakan pre test-post test. Populasinya adalah semua ibu yang mempunyai anak usia 0-3 tahun yang rutin membawa anaknya ke Posyandu di Posyandu 5 Kelurahan Srengat Kecamatan Srengat Kabupaten Blitar sabanyak 23 responden. Keseluruhan populasi digunakan sebagai sampel dengan teknik total sampling. Variabel yang digunakan adalah Independent Variable yaitu penyuluhan tentang stimulasi perkembangan anak usia 0-3 tahun dan Dependent Variable yaitu pengetahuan ibu sebelum dan sesudah diberi penyuluhan tentang stimulasi perkembangan anak usia 0-3 tahun. Pengumpulan data diperoleh menggunakan kuesioner, pengolahan data melalui editing, coding, scoring dan tabulating. Untuk menguji adanya perbedaan dilakukan analisa uji Wilcoxon Match Pair Test.

Hasil penelitian menunjukkan pengetahuan ibu sebelum diberi penyuluhan tertinggi dengan kriteria pengetahuan kurang, sebanyak 13 responden $(56,52 \%)$. Dan pengetahuan ibu setelah diberi penyuluhan tertinggi dengan kriteria pengetahuan baik sebanyak 15 responden (65,22\%). Dari uji Wilcoxon didapatkan hasil ada perbedaan pengetahuan ibu sebelum diberi penyuluhan dan setelah diberi penyuluhan tentang stimulasi perkembangan anak usia 0-3 tahun $(\sigma \leq 0,05)$.

Berdasarkan penelitian tersebut, dapat diketahui ada perbedaan pengetahuan ibu sebelum diberi penyuluhan dan setelah diberi penyuluhan tentang stimulasi perkembangan anak usia 0-3 tahun. Sehingga diharapkan ibu lebih aktif mencari informasi untuk menambah pengetahuan dan mendeteksi dini terjadinya keterlambatan perkembangan.
\end{abstract}

Kata kunci : Pengetahuan, Ibu, Penyuluhan, Stimulasi, Perkembangan, Anak 


\section{PENDAHULUAN}

Perkembangan juga berhubungan dengan proses belajar terutama mengenai isinya, yaitu mengenai apa yang harus berkembang berkaitan dengan tingkah laku belajar. Disamping itu juga bagaimana sesuatu itu dipelajari, apakah misalnya melalui memorisasi (menghafalkan) atau melalui peniruan dengan menangkap hubungan-hubungan, hal ini semua ikut menentukan proses perkembangan (Ahmadi, $2005:$ 1).

Setiap anak secara kodrat membawa variasi dan irama perkembangannya sendiri, perlu diketahui setiap orang tua, agar ia tidak bertanya-tanya bahkan bingung atau bereaksi negatif yang lain dalam menghadapi perkembangan anaknya. Bahkan ia harus bersikap tenang sambil mengikuti terus menerus pertumbuhan anaknya, agar pertumbuhan itu sendiri terhindar dari gangguan apapun, yang tentu saja akan merugikan (Ahmadi, $2005: 16$ ).

Supaya dapat mencapai hal tersebut, orang tua membutuhkan pendidikan ekstra, seperti bertanya dengan dokter, orang tua lain, organisasi kemasyarakatan setempat, sekolah, penitipan anak dan kelompokkelompok lain yang mempunyai spesialisasi dalam masalah anak. Sehingga orang tua akan lebih tahu (Shelov, 2005:6).

Melakukan deteksi dini penyimpangan tumbuh kembang artinya melakukan skrining atau mendeteksi dini adanya peyimpangan perkembangan balita termasuk menindaklanjuti setiap keluhan orang tua tehadap masalah tumbuh kembang 70 | Jurnal Kebidanan Dharma Husada Vol. 4, No. 2 Oktober 2015 anaknya. Melakukan intervensi dini perkembangan balita artinya melakukan tindakan koreksi dengan memanfaatkan otak anak untuk memperbaiki penyimpangan tumbuh kembang pada seorang anak agar tumbuh kembangnya kembali normal atau penyimpangan tidak semakin berat (Depkes RI, 2005 : 1).

Kurangnya stimulasi menyebabkan penyimpangan perkembangan anak bahkan gangguan yang menetap. Penyimpangan perkembangan ini bisa terjadi pada salah satu atau lebih kemampuan anak yaitu kemampuan gerak kasar, gerak halus, bicara dan bahasa, serta sosialisasi dan kemandirian anak (Depkes RI, 2005 : 1). Menurut Damayanti (2005), memperkirakan bahwa $48 \%$ anak Indonesia mengalami keterlambatan dalam perkembangan diantaranya dalam kemampuan sosialisasinya.

Berdasarkan studi pendahuluan yang dilakukan pada tanggal 5 April 2014 yang diberikan pada $10 \mathrm{ibu}$ yang memiliki balita usia 0-3 tahun dengan memberikan 5 pertanyaan pada ibu di Posyandu 5, Kelurahan Srengat, Kecamatan Srengat, Kabupaten Blitar terdapat $7(70 \%)$ ibu belum mengerti tentang stimulasi perkembangan anak dan $3(30 \%)$ ibu mengerti tentang stimulasi perkembangan anak.

Maka solusi yang akan diberikan yaitu, memberikan pengertian tentang stimulasi perkembangan, stimulasi yang dapat diberikan dan penyimpangan perkembangan pada anak usia 0-3 tahun, memberi pengarahan dan selalu mengingatkan 
kepada ibu untuk selalu mengikuti informasi tentang stimulasi perkembangan anak usia 0-3 tahun, melalui media-media informasi. Serta melakukan kegiatan stimulasi, deteksi dan intervensi dini penyimpangan tumbuh kembang anak yang menyeluruh dan terkoordinasi. (Depkes RI, 2005 : iii)

Berdasarkan latar belakang tersebut di atas menunjukkan bahwa orang tua masih jarang yang mengerti tentang pemberian stimulasi kepada balita, maka peneliti tertarik untuk melaksanakan penelitian dengan judul "Perbedaan Pengetahuan Ibu Sebelum Diberi Penyuluhan dan Setelah Diberi Penyuluhan tentang Stimulasi Perkembangan Anak Usia 0-3 Tahun di Posyandu 5, Kelurahan Srengat, Kecamatan Srengat, Kabupaten Blitar".

\section{METODE}

Desain yang akan digunakan dalam penelitian ini adalah pre experimental design dengan menggunakan pre test-post test, penelitian ini dilakukan dengan cara memberikan pretest (pengamatan awal) terlebih dahulu sebelum diberi intervensi. Setelah diberikan intervensi, kemudian dilakukan kembali posttest (pengamatan akhir) (Hidayat, $2008: 29$ ).

Pada penelitian ini populasinya adalah semua ibu yang mempunyai anak usia 0-3 tahun yang rutin membawa anaknya ke posyandu di Posyandu 5 Kelurahan Srengat Kecamatan Srengat Kabupaten Blitar, yang berjumlah 23 orang. Sampel yang diambil dalam penelitian ini adalah ibu yang mempunyai anak usia 0-3 tahun yang rutin membawa anaknya ke posyandu di Posyandu 5 Kelurahan Srengat Kecamatan Srengat Kabupaten Blitar Tahun 2014, yang berjumlah 23 orang.

Pada penelitian ini teknik sampling yang digunakan adalah pengambilan sampel total atau Total Sampling.

Dalam penelitian ini variabel bebasnya adalah penyuluhan tentang stimulasi perkembangan anak usia 0-3 tahun. Dalam penelitian ini variabel terikatnya adalah pengetahuan ibu sebelum diberi penyuluhan dan setelah diberi penyuluhan tentang stimulasi perkembangan anak usia 0-3 tahun. 
Tabel III.1 Definisi Operasional Perbedaan Pengetahuan Ibu Sebelum Diberi Penyuluhan dan Setelah Diberi Penyuluhan tentang Stimulasi Perkembangan Anak Usia 0-3 Tahun Pengetahuan dan Sikap Akseptor KB Aktif tentang Kontrasepsi Implan di BPM Ny. Agustina

\begin{tabular}{|c|c|c|c|c|c|c|}
\hline No & Variabel & $\begin{array}{c}\text { Definisi } \\
\text { Operasional }\end{array}$ & Indikator & Instrumen & Skala & Keterangan \\
\hline 1. & $\begin{array}{l}\text { Variabel } \\
\text { independen : } \\
\text { penyuluhan } \\
\text { tentang stimulasi } \\
\text { perkembangan } \\
\text { anak usia 0-3 } \\
\text { tahun }\end{array}$ & $\begin{array}{l}\text { Memberikan } \\
\text { pendidikan } \\
\text { kesehatan kepada } \\
\text { ibu yang memiliki } \\
\text { anak usia 0-3 tahun } \\
\text { tentang stimulasi } \\
\text { perkembangan } \\
\text { anak usia 0-3 tahun } \\
\text { di Kelurahan } \\
\text { Srengat Kecamatan } \\
\text { Srengat Kabupaten } \\
\text { Blitar }\end{array}$ & $\begin{array}{l}\text { Indikator yang sesuai } \\
\text { SAP adalah: } \\
\text { 1) Pengertian } \\
\text { tentang stimulasi } \\
\text { perkembangan anak } \\
\text { 2) Prinsip dasar } \\
\text { dalam pemberian } \\
\text { stimulasi } \\
\text { 3) Pembangian } \\
\text { kelompok stimulasi } \\
\text { sesuai umur anak } \\
\text { 4) Stimulasi } \\
\text { perkembangan gerak } \\
\text { kasar } \\
\text { 5) Stimulasi } \\
\text { perkembangan gerak } \\
\text { halus } \\
\text { 6) Stimulasi } \\
\text { perkembangan bicara } \\
\text { dan bahasa } \\
\text { 7) Stimulasi } \\
\text { perkembangan } \\
\text { sosialisasi } \\
\text { kemandirian dan }\end{array}$ & $\begin{array}{l}\mathrm{L} \\
\mathrm{E} \\
\mathrm{A} \\
\mathrm{F} \\
\mathrm{L} \\
\mathrm{E} \\
\mathrm{T}\end{array}$ & & \\
\hline 2. & $\begin{array}{l}\text { Variabel } \\
\text { dependen : } \\
\text { Pengetahuan ibu } \\
\text { sebelum dan } \\
\text { sesudah diberi } \\
\text { penyuhan tentang } \\
\text { stimulasi } \\
\text { perkembangan } \\
\text { anak usia 0-3 } \\
\text { tahun }\end{array}$ & $\begin{array}{l}\text { Segala sesuatu } \\
\text { yang diketahui ibu } \\
\text { tentang stimulasi } \\
\text { perkembangan } \\
\text { anak usia 0-3 tahun } \\
\text { di Posyandu } 5 \\
\text { Kelurahan Srengat } \\
\text { Kecamatan Srengat } \\
\text { Kabupaten Blitar }\end{array}$ & $\begin{array}{l}\text { Pengetahuan ibu } \\
\text { tentang: } \\
\text { 1) Pengertian } \\
\text { tentang stimulasi } \\
\text { perkembangan anak } \\
\text { 2) Prinsip dasar } \\
\text { pemberian stimulasi } \\
\text { 3) Pembangian } \\
\text { kelompok stimulasi } \\
\text { sesuai umur anak } \\
\text { 4) Stimulasi } \\
\text { perkembangan gerak } \\
\text { kasar } \\
\text { 5) Stimulasi } \\
\text { perkembangan gerak } \\
\text { halus } \\
\text { 6) Stimulasi } \\
\text { perkembangan bicara } \\
\text { dan bahasa } \\
\text { 7) Stimulasi } \\
\text { perkembangan } \\
\text { sosialisasi } \\
\text { kemandirian }\end{array}$ & $\begin{array}{l}\mathrm{K} \\
\mathrm{U} \\
\mathrm{E} \\
\mathrm{S} \\
\mathrm{I} \\
\mathrm{O} \\
\mathrm{N} \\
\mathrm{E} \\
\mathrm{R}\end{array}$ & $\begin{array}{l}\mathrm{O} \\
\mathrm{R} \\
\mathrm{D} \\
\mathrm{I} \\
\mathrm{N} \\
\mathrm{A} \\
\mathrm{L}\end{array}$ & $\begin{array}{l}\text { Bila jawaban } \\
\text { Benar: } 1 \\
\text { Salah : } 0 \\
\text { Kategori } \\
\text { pengetahuan: } \\
\text { Baik : } 76 \%-100 \% \\
\text { Cukup : 56\%-75\% } \\
\text { Kurang : >56\% } \\
\text { (Wawan \& Dewi, } \\
\text { 2011: } 18 \text { ) }\end{array}$ \\
\hline
\end{tabular}


Instrumen yang digunakan pada penelitian ini adalah kuesioner bersifat tertutup. Uji statistik yang digunakan dalam penelitian ini adalah teknik uji Chi kuadrat (Chi Square). Dalam penelitian ini ada dua kuesioner yang digunakan untuk pengumpulan data, yaitu kuesioner pertama yang diberikan sebelum diberi penyuluhan dan kuesioner ke dua diberikan setelah penyuluhan. Masing-masing berupa 20 pertanyaan tertutup yaitu kuesioner yang sudah tersedia jawabannya, sehingga responden tinggal memilih satu jawaban yang telah disediakan dengan menggunakan multiple choice, yaitu daftar pertanyaan yang menyediakan beberapa jawaban atau alternatif, dan responden hanya memilih satu diantaranya yang sesuai dengan pendapatnya. Kuesioner sebelumnya telah dilakukan uji validitas dan uji reliabilitas menggunakan computer.

Penelitian dilakukan di Posyandu 5 Kelurahan Srengat Kecamatan Srengat
Kabupaten Blitar. Tekhnik pengolahan data dengan editing, koding, skoring, dan tabulating. Teknik analisis data dengan prosentase.

$$
P=\frac{x}{y} X 100 \%
$$

Keterangan:

$\mathrm{P} \quad$ : Prosentase

x : Skor yang didapat

y : Skor total

Hasil prosentase dari skor yang diperoleh untuk pengolahan data setiap variabel diinterpretasikan dengan skala kualitatif sebagai berikut:

1. Baik : Hasil Prosentase 76\% $100 \%$

2. Cukup : Hasil Prosentase 56\% $75 \%$

3. Kurang : Hasil Prosentase $<56 \%$ (Wawan dan Dewi, $2010: 18$ )

\section{DISKUSI}

\section{Pengetahuan Ibu Sebelum Diberi penyuluhan tentang Stimulasi} Perkembangan Anak Usia 0-3 Tahun

Tabel IV.4 Distribusi Frekuensi Pengetahuan Ibu Sebelum Diberi Penyuluhan Tentang Stimulasi Perkembangan Anak Usia 0-3 Tahun di Posyandu 5 Kelurahan Srengat Kecamatan Srengat Kabupaten Blitar

\begin{tabular}{|c|c|c|}
\hline Kriteria Pengetahuan & Frekuensi & Prosentase (\%) \\
\hline Baik & 1 & 4 \\
\hline Cukup & 9 & 39 \\
\hline Kurang & 13 & 57 \\
\hline Total & 23 & 100 \\
\hline
\end{tabular}

Berdasarkan tabel IV.4 dapat menunjukkan pengetahuan ibu sebelum diberi penyuluhan tentang stimulasi perkembangan anak usia 0-3 tahun di posyandu 5 Kelurahan Srengat Kecamatan Srengat Kabupaten Blitar kriteria pengetahuan 
tertinggi sejumlah 13 orang (57\%) mempunyai pengetahuan dengan kriteria kurang.

\section{Pengetahuan Ibu Setelah Diberi Penyuluhan tentang Stimulasi} Perkembangan Anak Usia 0-3 Tahun

Tabel IV.5 Distribusi Frekuensi Pengetahuan Ibu Setelah Diberi Penyuluhan Tentang Stimulasi Perkembangan Anak Usia 0-3 Tahun di Posyandu 5 Kelurahan Srengat Kecamatan Srengat Kabupaten Blitar

\begin{tabular}{lccc} 
& Kriteria Pengetahuan & Frekuensi & Prosentase (\%) \\
\hline Baik & 15 & 65 \\
\hline Cukup & & 5 & 22 \\
\hline Kurang & Total & 3 & 3 \\
\hline & & 23 & 100
\end{tabular}

Berdasarkan tabel IV.5 di atas, menunjukkan bahwa pengetahuan ibu setelah diberi penyuluhan tentang stimulasi perkembangan anak usia 0-3 tahun di posyandu 5 Kelurahan Srengat Kecamatan Srengat Kabupaten Blitar kriteria pengetahuan tertinggi yaitu sejumlah 15 orang $(65 \%)$.

3. Analisa Perbedaan Pengetahuan Ibu Sebelum Diberi Penyuluhan dan Setelah Diberi Penyuluhan tentang Stimulasi Perkembangan Anak Usia 0-3 Tahun

Tabel IV.6 Distribusi Frekuensi Perbedaan Pengetahuan Ibu Sebelum Diberi Penyuluhan dan Setelah Diberi Penyuluhan Tentang Stimulasi Perkembangan Anak Usia 0-3 Tahun di Posyandu 5 Kelurahan Srengat Kecamatan Srengat Kabupaten Blitar

\begin{tabular}{cccccccc}
\multirow{2}{*}{ No. } & Pengetahuan & \multicolumn{2}{c}{ Baik } & \multicolumn{2}{c}{ Cukup } & \multicolumn{2}{c}{ Kurang } \\
\cline { 3 - 8 } & & $\mathbf{F}$ & $\mathbf{\%}$ & $\mathbf{f}$ & $\mathbf{\%}$ & $\mathbf{f}$ & $\mathbf{\%}$ \\
\hline 1. & Sebelum diberi penyuluhan & 1 & 4 & 9 & 39 & 13 & 57 \\
\hline 2. & Sesudah diberi penyuluhan & 15 & 65 & 5 & 22 & 3 & 13 \\
\hline \multicolumn{2}{c}{ Total } & $\mathbf{1 6}$ & $\mathbf{1 0 0}$ & $\mathbf{1 4}$ & $\mathbf{1 0 0}$ & $\mathbf{1 6}$ & $\mathbf{1 0 0}$
\end{tabular}

Berdasarkan tabel IV.6 di atas, menunjukkan bahwa hasil pengujian perbedaan pengetahuan ibu sebelum diberi penyuluhan dan setelah diberi penyuluhan tentang stimulasi perkembangan anak usia 0-3 tahun di Posyandu 5 Kelurahan srengat Kecamatan Srengat Kabupaten Blitar mempunyai kriteria pengetahuan baik. Dengan menggunakan 2 related simple test disajikan dalam tabel berikut : 
Tabel IV.7 Hasil Analisis Perbedaan Pengetahuan Ibu Sebelum Diberi Penyuluhan dan Setelah Diberi Penyuluhan tentang Stimulasi Perkembngan Anak Usia 0-3 Tahun di Posyandu 5 Kelurah 35 Srengat Kecamatan Srengat Kabupaten Blitar

\begin{tabular}{llrrr}
\multicolumn{5}{c}{ Ranks } \\
& \multicolumn{5}{c}{ N } & Mean Rank & Sum of Ranks \\
\hline Sesudah - & Negative Ranks & $0^{\mathrm{a}}$ & .00 & .00 \\
\cline { 2 - 5 } Sebelum & Positive Ranks & $22^{\mathrm{b}}$ & 11.50 & 253.00 \\
\cline { 2 - 5 } & Ties & $1^{\mathrm{c}}$ & & \\
\cline { 2 - 5 } & Total & 23 & & \\
\hline
\end{tabular}

Keterangan :

A. Sesudah $<$ Sebelum

B. Sesudah $>$ Sebelum

C. Sesudah $=$ Sebelum

Berdasarkan tabel di atas dapat diketahui bahwa yang mengalami kenaikan tingkat pengetahuan ada 22 responden (96\%), yang memiliki pengetahuan tetap ada 1 responden $(4 \%)$.

Tabel IV.8 Hasil Uji Statistik Perbedaan Pengetahuan Ibu Sebelum Diberi Penyuluhan dan Setelah Diberi Penyuluhan tentang Stimulasi Perkembangan Anak Usia 0-3 Tahun di Posyandu 5 Kelurahan Srengat Kecamatan Srengat Kabupaten Blitar Test Statistics ${ }^{b}$

\begin{tabular}{|l|r|}
\hline & $\begin{array}{c}\text { SESUDAH - } \\
\text { SEBELUM }\end{array}$ \\
\hline$Z$ & $-4.125^{\mathrm{a}}$ \\
Asymp. Sig. (2-tailed) & .000 \\
\hline
\end{tabular}

Keterangan :

a. Based on negative ranks.

b. Wilcoxon Signed Ranks Test

Berdasarkan hasil uji statistik dengan menggunakan Wilcoxon Match pair Test di atas menunjukkan hasil $\mathrm{Z}$ sebesar $-4,125$ dengan tingkat signifikansi $(\sigma)$ sebesar $0,000(\sigma \leq 0,05)$. Karena nilai $\sigma \leq 0,05$ maka $\mathrm{H} 0$ di tolak dan $\mathrm{H} 1$ diterima yang artinya ada perbedaan pengetahuan ibu sebelum diberi penyuluhan dan setelah diberi penyuluhan tentang stimulasi perkembangan anak usia 0-3 tahun. 


\section{Pengetahuan Ibu Sebelum Diberi Penyuluhan Tentang Stimulasi Perkembangan Anak Usia 0-3 Tahun Di Posyandu 5 Kelurahan Srengat Kecamatan Srengat Kabupaten Blitar}

Berdasarkan tabulasi data hasil menunjukkan bahwa sebagian besar ibu berpengetahuan kurang sejumlah 13 orang $(56,52 \%)$ dan sejumlah 9 orang (39,13\%) berpengetahuan cukup, selanjutnya sebanyak 1 orang $(4,35 \%)$ berpengetahuan baik.

Pengetahuan seseorang akan berpengaruh pada kehidupannya sehari-hari. Maka dari itu pengetahuan sangat penting untuk meningkatkan kualitas hidup setiap individu. Karena pengetahuan adalah kesan di dalam pikiran manusia sebagai hasil penggunaan pancainderanya (Mubarak, 2011 : 81). Selain itu faktor lain yang dapat mempengaruhi pengetahuan responden, yaitu pekerjaan responden yang sebagian besar responden bekerja sebagai wiraswasta sebanyak 11 responden $(47,83 \%)$ dan responden yang tidak bekerja sejumlah 8 responden $(34,78 \%)$.

Menurut Thomas pekerjaan adalah keburukan yang harus dilakukan terutama untuk menunjang kehidupannya dan keluarga (Wawan, $2011: 18$ ).

Adanya hasil penelitian bahwa responden memiliki pengetahuan kurang yang salah satunya disebabkan oleh pekerjaan. Hal ini bisa dikarenakan kesibukan seorang ibu sebagai wirausaha, hanya memiliki waktu sedikit di rumah sehingga mereka kurang memperhatikan perkembangan anaknya, apalagi untuk mencari informasi tentang stimulasi perkembangan anak usia 0-3 tahun. Selain itu, seorang ibu rumah tangga cenderung berada di rumah dan tidak mendapatkan konstribusi pengetahuan dari luar. Namun tidak semua ibu rumah tangga memiliki pengetahuan kurang, semua tergantung pada setiap responden itu sendiri. Jika responden dapat menggunakan waktu luang sebaik-baiknya, dengan mencari informasi tentang stimulasi perkembangan anak usia 0-3 tahun dengan membaca buku, majalah, media-media modern seperti televisi dan radio, maka tidak menutup kemungkinan mereka dapat memiliki pengetahuan baik pula. Sehingga diharapkan responden dapat lebih paham tentang apa yang di maksud tentang stimulasi perkembangan anak usia 0-3 tahun.

Berdasarkan hasil penelitian yang telah dilakukan pada 23 responden. Terdapat kriteria kurang terbanyak pada pengetahuan ibu tentang pembagian kelompok stimulasi sesuai umur anak, yaitu sebanyak 17 responden $(73,91 \%)$.

Karena perkembangan kemampuan dasar anak mempunyai pola yang tetap dan berlangsung berurutan. Dengan demikian stimulasi yang diberikan oleh orang tua khususnya oleh ibu harus sesuai dengan pembagian kelompok umur stimulasi anak yaitu masa janin dalam kandungan, masa anak usia 0-12 bulan, masa anak balita 12-60 bulan dan masa prasekolah 60-72 bulan (Depkes RI, 2005 : 15).

Pembagian kelompok stimulasi sesuai umur anak sebenarnya sangat perlu diketahui oleh para orang tua khususnya oleh ibu. Karena dengan mereka paham dan mengerti mereka 
akan memberikan stimulasi sesuai umur anak, sehingga anak akan memiliki kematangan perkembangan yang sesuai dan dapat mencegah terjadinya keterlambatan perkembangan pada anak.

\section{Pengetahuan Ibu Setelah}

Diberi Penyuluhan Tentang Stimulasi Perkembangan Anak Usia 0-3 Tahun Di Posyandu 5 Kelurahan Srengat Kecamatan Srengat Kabupaten Blitar

Berdasarkan tabel IV.7 dapat menunjukkan dari 30 responden yang diteliti, terdapat 17 responden $(57 \%)$ memiliki sikap positif, dan 13 responden (43\%) memiliki sikap negatif.

Berdasarkan tabulasi data hasil penelitian mengenai pengetahuan ibu setelah diberi penyuluhan tentang stimulasi perkembangan anak usia 0-3 tahun di Posyandu 5 Kelurahan Srengat Kecamatan Srengat Kabupaten Blitar dengan 23 responden menunjukkan bahwa sebagian besar pengetahuan meningkat baik sejumlah 15 orang $(65 \%)$ dan sejumlah 5 orang $(22 \%)$ berpengetahuan cukup, selanjutnya sebanyak 3 orang (13\%) berpengetahuan kurang.

Dari data di atas menunjukkan adanya peningkatan pengetahuan setelah dilakukan penyuluhan. Itu menunjukkan bahwa dengan di selenggarakannya penyuluhan dapat menambah atau menekankan apa yang sudah dipelajari, mengulangi, memperkenalkan atau mengantarkan suatu pelajaran atau aktivitas, dan responden dapat memahami kata-kata yang digunakan oleh penyuluh (Mubarak, 2011 : 131). Faktor lain yang berpengaruh terhadap pengetahuan responden yaitu dari pendidikan. Berdasarkan hasil penelitian, didapatkan bahwa sebagian besar responden memiliki pendidikan akhir SMP sebanyak 12 responden $(52 \%)$.

Dari hasil penelitian tersebut dapat dikatakan bahwa semakin tinggi pendidikan seseorang maka akan semakin mudah mereka dalam menerima dan memahami setiap informasi yang mereka dapatkan. Hal ini sesuai dengan teori yang menyebutkan bahwa faktor-faktor yang mempengaruhi pengetahuan salah satunya adalah pendidikan, yang berarti bimbingan yang diberikan seseorang terhadap perkembangan orang lain menujukearah cita-cita tertentu. Pendidikan diperlukan untuk mendapat informasi misalnya hal-hal yang menunjang kesehatan sehingga dapat meningkatkan kualitas hidup (Wawan \& Dewi, 2011 : 16).

Semua informasi yang didapat individu tersebut dapat merubah sikap, tingkah laku dan pola pikir dalam kehidupannya. Selain itu juga akan menambah tingkat keingintahuan seseorang akan informasi yang belum mereka pahami atau bahkan yang sama sekali mereka belum ketahui. Sehingga dapat membawa perubahan yang lebih baik dan memberi lebih banyak dampak positif bagi kehidupan setiap individu, serta orang-orang yang ada di sekitarnya. Karena perubahan baik tersebut akan membuat seseorang lebih peka dalam menghadapi segala hal sehingga mereka tahu mana yang boleh di lakukan dan mana yang tidak boleh dilakukan. 
Berdasarkan hasil penelitian yang telah dilakukan, kriteria pengetahuan baik terbanyak setelah diberi penyuluhan pada pengetahuan ibu tentang pengertian stimulasi perkembangan sejumlah 20 responden $(87 \%)$.

Menurut

Wawan

pengetahuan merupakan hasil tahu dan ini terjadi setelah orang mengadakan penginderaan terhadap suatu objek tertentu. Penginderaan terdadap objek terjadi melalui panca indera manusia yakni penglihatan, pendengaran, penciuman, raba dan rasa itu sendiri. Sedangkan sebagian besar pengetahuan manusia diperoleh melalui mata dan telinga.

Berdasarkan penjelasan teori di atas, responden mempunyai proses mendapatkan pengetahuan yang didapatkan sebelum akhirnya akan menerapkan pengetahuan yang baru didapatkan, sehingga responden mampu menguasai lingkungan sekitarnya. Selain itu responden juga akan mampu mengatasi masalah yang terjadi serta mampu menghadapi segala pembaharuan yang terjadi dari pengetahuan yang diperoleh. Maka dari itu untuk lebih meningkatkan pengetahuannya, responden sebaiknya juga aktif mencari informasi terkini dari media-media lain, serta menyebarkan informasi yang didapat tersebut ke responden lain yang belum tahu, sehingga komunikasi yang baik dapat terwujud.

\section{Perbedaan Pengetahuan Ibu} Sebelum Diberi Penyuluhan dan Setelah Diberi Penyuluhan Tentang Stimulasi Perkembangan Anak Usia 0-3

\section{Tahun Di Posyandu 5 Kelurahan Srengat Kecamatan Srengat Kabupaten Blitar}

Hasil uji statistik yang dilakukan dengan uji Wilcoxon Match pair Test pada 23 responden yang dilakukan menggunakan computer menghasilkan nilai $\mathrm{Z}$ sebesar $-4,125$ dengan nilai signifikan $(\sigma)$ sebesar 0,000 . Hal ini berarti nilai signifikansi perbedaan pengetahuan ibu sebelum diberi penyuluhan dan setelah diberi penyuluhan dengan tingkat kesalahan $(\sigma) 5 \%$ atau 0,05 sebesar $0,000(\sigma \leq$ $0,05)$. Dari hasil analisis, menunjukkan bahwa pengetahuan responden sebelum diberi penyuluhan dibandingkan setelah diberi penyuluhan terjadi peningkatan sebanyak 22 responden $(95,65 \%)$, dengan tingkat signifikansi $(\sigma)=0,000 \quad(\sigma \leq 0,05)$, maka H1 diterima, yang artinya ada perbedaan antara pengetahuan ibu sebelum diberi penyululan dan setelah diberi penyuluhan tentang stimulasi perkembangan anak usia 0-3 tahun.

Adanya perbedaan pengetahuan ibu tentang stimulasi perkembangan anak usia 0-3 tahun ditunjang oleh data khusus. Peningkatan terbanyak yaitu pada kategori baik dengan hasil 15 orang $(65 \%)$ yang pada awalnya hanya terdapat 1 orang $(4 \%)$ atau perjadi peningkatan $(61 \%)$.

Pengetahuan akan terus berkembang dengan seiring perkembangan zaman. Pengetahuan tentang stimulasi perkembangan anak usia 0-3 tahun akan lebih mematangkan perkembangan kemampuan dasar anak yang mempunyai pola yang tetap dan berlangsung secara berurutan. Dengan demikian stimulasi diberikan kepada anak dalam rangka merangsang 
pertumbuhan dan perkembangan anak dapat diberikan oleh orang tua atau keluarga sesuai dengan pembagian kelompok umur stimulasi (Dinkes RI, $2005: 15)$.

Stimulasi perkembangan tersebut sebenarnya sangat penting bagi kelangsungan perkembangan anak. Dengan dilakukannya stimulasi oleh orang tua atau keluarga dengan yang benar, akan dapat mence 39 terjadinya keterlambatan perkembangan pada anak. Karena jika kereterlambatan tersebut tidak terdeteksi dan dilakukan intervensi secara dini ditakutkan dapat menyebabkan gangguan perkembangan yang menetap pada anak. Maka dari itu pengetahuan tersebut sangat dibutuhkan oleh orang tua, terutama oleh ibu, supaya mereka lebih tanggap jika mengetahui adanya keterlambatan perkembangan yang dialami oleh anak.

Perbedaan pengetahuan ibu sebelum diberi penyuluhan dan setelah diberi penyuluhan tentang stimulasi perkembangan anak usia 0-3 tahun terlihat dari isian kuesioner dimana pada umumnya terjadi peningkatan pengetahuan. Sebelum dilakukan penyuluhan terdapat nilai rendah pada kuesioner tentang pengertian stimulasi atau rangsangan perkembangan dengan hanya bernilai (52\%), setelah diberi penyuluhan menjadi (91\%). Selain itu terdapat pula nilai yang tetap pada kuesioner tentang mengangkat kepala

\section{SIMPULAN}

1. Pengetahuan ibu sebelum diberi penyuluhan tentang stimulasi perkembangan anak usia 0-3 tahun menunjukkan pengetahuan yang kurang yaitu sebesar (57\%). berguling-guling

merangkak merupakan contoh dari rangsangan gerak kasar yaitu dengan nilai (61\%). Namun tidak ada penurunan nilai pada soal-soal lain.

Keberhasilan penyuluhan juga tergantung pada ketepatan sasaran dalam dan langkah-langkah pemberian penyuluhan misalnya mengenal masalah, karakteristik masyarakat dan wilayah setempat. Selain itu menentukan prioritas masalah, tujuan, sasaran, isi, metode, media atau alat bantu, melakukan penilaian serta memuat rencana jadwal pelaksanaan merupakan hal-hal yang dapat mendukung terhadap keberhasilan suatu kegiatan penyuluhan (Hikmawati, 2011 : 138).

Pada kenyataannya, kegiatan penyuluhan masih efektif untuk pemberian informasi kepada masyarakat. Sehingga diharapkan petugas kesehatan lebih sering memberikan informasi atau penyuluhan kepada masyarakat khususnya ibu-ibu tentang stimulasi perkembangan anak usia 0-3 tahun agar ibu lebih paham dan dapat menerapkannya di rumah. Apabila pengetahuan tersebut diterapkan oleh ibu terhadap buah hatinya di rumah, maka secara tidak langsung para peneliti telah ikut berperan dalam menurunkan angka keterlambatan perkembangan pada anak usia 0-3 tahun.

2. Pengetahuan ibu setelah diberi penyuluhan tentang stimulasi perkembangan anak usia 0-3 tahun menunjukkan pengetahuan yang baik yaitu sebesar $(65 \%)$. 
3. Ada perbedaan pengetahuan ibu sebelum diberi penyuluhan dan setelah diberi penyuluhan tentang stimulasi perkembangan anak usia

\section{DAFTAR PUSTAKA}

Ahamdi, Abu. 2005. Psikologi Perkembangan. Jakarta : PT. Rineka Cipta

Arikunto, Suharsimi. 2010. Prosedur Penelitian. Jakarta: Rineka Cipta

Depkes RI. 2005. Stimulasi, Deteksi dan Intervensi Dini Tumbuh Kembang Anak. Jakarta : Depkes RI

Hidayat, A.Aziz Alimul. 2005. Pengantar Ilmu Keperawatan Anak 1. Jakarta : Salemba Medika 2007. Metode Penelitian Kebidanan Teknik Analisis Data. Jakarta : Salemba Medika 2008. Riset Keperawatan dan Teknik Penulisan Ilmiah. Jakarta : Salemba Medika

2008. Pengantar Ilmu Kesehatan Anak untuk Pendidikan Kebidanan. Jakarta : Salemba Medika

2009. Metode Penilitian Keperawatandan Teknik Analisa Data. Jakarta : Salemba Medika

Hikmawati, Isna. 2011. Promosi Kesehatan untuk Kebidanan. Yogyakarta : Nuha Medika

Kartono, Kartini. 2007. Psikologi Anak. Bandung : CV. Mandar Maju

Tim Penyusun Pusat Kamus. 2008. Kamus Besar Bahasa Indonesia. Jakarta : PT. Gramedia Pustaka Utama

Machfoedz, Ircham. 2006. Pendidikan Kesehatan Bagian dari Promosi Kesehatan. Yogyakarta : Fitramaya
0-3 tahun di Posyandu 5 Kelurahan Srengat Kecamatan Srengat Kabupaten

Blitar

Mubarok, Wahid Iqbal. 2011. Promosi Kesehatan untuk Kebidanan. Jakarta : Salemba Medika

Notoatmodjo, Soekidjo. 2005. Metodologi Penelitian Kesehatan. Jakarta : PT Rineka Cipta . 2007. Promosi Kesehatan dan Ilmu Perilaku. Jakarta : PT. Rineka Cipta

Nursalam. 2008. Konsep dan Penerapan Metodologi Penelitian Ilmu Keperawatan. Jakarta : Salemba Medika

Shelov, Steven P. 2005. Perawatan untuk Bayi dan Balita. Jakarta : Arcan

Soetjiningsih. 2007. Tumbuh Kembang Anak. Jakarta : EGC

Sugiyono. 2005. Metode Penelitian Administrasi. Bandung : CV Alfabeta

Wawan dan Dewi. 2011. Pengetahuan, Sikap, dan Perilalaku Manusia. Yogyakarta: Nuha Medika

Amelia, Hektania. 2010. Tanda-tanda Gangguan Bahasa. [internet]. 20, Juni, Available from : http//www.klipingut.wordpress.com/ gangguan-perkembangan-bahasapada-anak, [accsessed on April 2014]

Chakim, M. Lutfi . 2012. Perlindungan Terhadap Anak yang Berhadapan dengan Hukum, Avaiable from : http//www.

Lutfichakim.blogspot.com/2012/12/p erlindungan-terhadap-anak-yang.html 